\title{
Changes in the Properties of Gap Junctions during Neuronal Differentiation of Hippocampal Progenitor Cells
}

\author{
Renato Rozental, ${ }^{1,2,6}$ Mildred Morales, ${ }^{1}$ Mark F. Mehler, ${ }^{1,3,4}$ Marcia Urban, ${ }^{1}$ Marion Kremer, ${ }^{7}$ Rolf Dermietzel, ${ }^{7}$ \\ John A. Kessler, ${ }^{1,3}$ and David C. Spray ${ }^{1,5,6}$ \\ Departments of ${ }^{1}$ Neuroscience, ${ }^{2}$ Anesthesiology, ${ }^{3}$ Neurology, ${ }^{4}$ Psychiatry, and ${ }^{5}$ Medicine, Albert Einstein College of \\ Medicine, Bronx, New York, 10461, 'Department of Internal Medicine and IPTESP, Federal University of Goiś, Goiânia \\ 74000, Brazil, and 7 Ruhr University Bochum, D-44780 Bochum, Germany
}

The cellular mechanisms that regulate progenitor cell lineage elaboration and maturation during embryonic development of the mammalian brain are poorly understood. Conditionally immortalized mouse hippocampal multipotent progenitor cells (MK31 cells) were found to be strongly coupled by gap junctions comprising connexin $43(\mathrm{Cx} 43)$ during early neuronal ontogeny; the presence of this $\mathrm{Cx}$ type was confirmed by electrophysiological, molecular biological, and immunocytochemical assays. However, as progenitor cells underwent intermediate stages of neuronal differentiation under the influence of interleukin 7 (IL-7) alone or terminal differentiation after composite exposure to basic fibroblast growth factor, IL-7, and transforming growth factor $\alpha$, coupling strength and the level of Cx43 expression declined. An additional population of junctional channels with distinct properties was detected at an intermediate stage of neuronal differentiation. Reverse transcription-PCR assays detected mRNA encoding Cx40 in IL-7-treated cells and $\mathrm{C} \times 33$ after both treatment conditions. Because functional channels in exogenous expression systems are not formed by pairing $\mathrm{Cx} 40$ with $\mathrm{Cx} 43$ or by pairing $\mathrm{C} \times 33$ with itself or additional connexins, these experimental observations raise the possibility that the progressive loss of coupling during differentiation of neural progenitor cells may involve downregulation of $\mathrm{Cx} 43$ coupled with potentiation of expression of $\mathrm{C} \times 33$ and Cx40. Furthermore, continued expression of Cx43 in differentiating neuroblasts could mediate intercellular communication between neuronal precursor cells and astrocytes by direct signaling via homotypic gap junction channels.

Key words: connexins; electrotonic coupling; development; cytokines; Cx33; Cx40; Cx43
Gap junction channels mediate intercellular communication in most tissues and organ systems (Dermietzel and Spray, 1993). These channels allow bidirectional exchange of ions and small molecules between cells, coupling the cells both electrotonically and metabolically. The proteins (connexins) forming gap junctions are encoded by a large multigene family of more than a dozen members in mammals (Willecke et al., 1993; Kumar and Gilula, 1996). The biophysical properties of gap junctions, such as channel conductance and selective permeability, are dictated by the connexin types and their phosphorylation state (Spray, 1994).

Gap junction-mediated intercellular communications appear to be required for normal cellular development as well as for tissue differentiation (Furshpan and Potter, 1968; Lowenstein, 1979; Dermietzel and Spray, 1993). The critical role of gap junctions during embryogenesis may be to provide intercellular pathways for morphogens and other developmentally relevant factors, including $\mathrm{Ca}^{2+}$ and a range of additional second messenger molecules. Either the exchange of such cytoplasmic factors or a decrease in their exchange may initiate programs of subsequent cellular differentiation.

Received Aug. 20, 1997; revised Dec. 5, 1997; accepted Dec. 8, 1997.

This work was supported by grants from the National Science Foundation Minority Postdoctoral Fellowship (M.M.), Muscular Dystrophy Association (M.F.M. and D.C.S.), Irma T. Hirschl Career Scientist Award (M.F.M.), and National Institutes of Health (R.R., M.F.M., J.A.K., and D.C.S.). We thank C. Roy, D. M. Vieira, and H. Rubin for technical expertise.

R.R., M.M., and D.C.S. contributed equally to this work.

Correspondence should be addressed to Dr. Renato Rozental, Albert Einstein College of Medicine, Department of Neuroscience, Kennedy Center Room 602, 1300 Morris Park Avenue, Bronx, NY 10461.

Copyright (C) 1998 Society for Neuroscience $\quad 0270-6474 / 98 / 181753-10 \$ 05.00 / 0$
Studies of neural development have been fostered by the introduction of immortalized precursor cells that can be manipulated in vitro toward graded stages of cellular differentiation (Mehler et al., 1995). Our approach has been to use a conditionally immortalized hippocampal cell line (MK31) that is developmentally responsive to a specific set of cytokines: interleukin 7 (IL-7), in concert with two other growth factors found in the developing brain, basic fibroblast growth factor (bFGF) and transforming growth factor $\alpha$ (TGF $\alpha$ ) (Mehler et al., 1993; Rozental et al., 1995). IL-7 has been detected in embryonic and adult murine brain and has been shown to possess neuronotrophic actions on primary hippocampal cultures examined in vitro (Araujo and Cotman, 1993; Michaelson et al., 1996).

We have shown that electrotonic coupling is quite strong among embryonic cells destined to become neurons, but that coupling strength declines during the progressive differentiation of MK31 neuroblasts treated with IL-7 alone or with the combination of $\mathrm{bFGF}(\mathrm{IL}-7$ and $\mathrm{TGF} \alpha$ ); each group displayed a distinctive developmental phenotype (Mehler et al., 1993; Rozental et al., 1995). Untreated MK31 neuroblasts were inexcitable, whereas $10 \%$ of IL-7-treated cells and $20 \%$ of cells treated with bFGF(IL-7 and TGF $\alpha$ ) were excitable; neurotransmitter responses were absent, with the exception of cells treated with bFGF(IL-7 and TGF $\alpha$ ) that were responsive to GABA ( $\geq 100$ $\mu \mathrm{M})$ (Rozental et al., 1995).

In the present study, we have used a variety of methods [Northern blot analyses, reverse transcription (RT)-PCR assays, and electrophysiological techniques] to identify the connexins that are expressed during neuronal differentiation in vitro. These experi- 

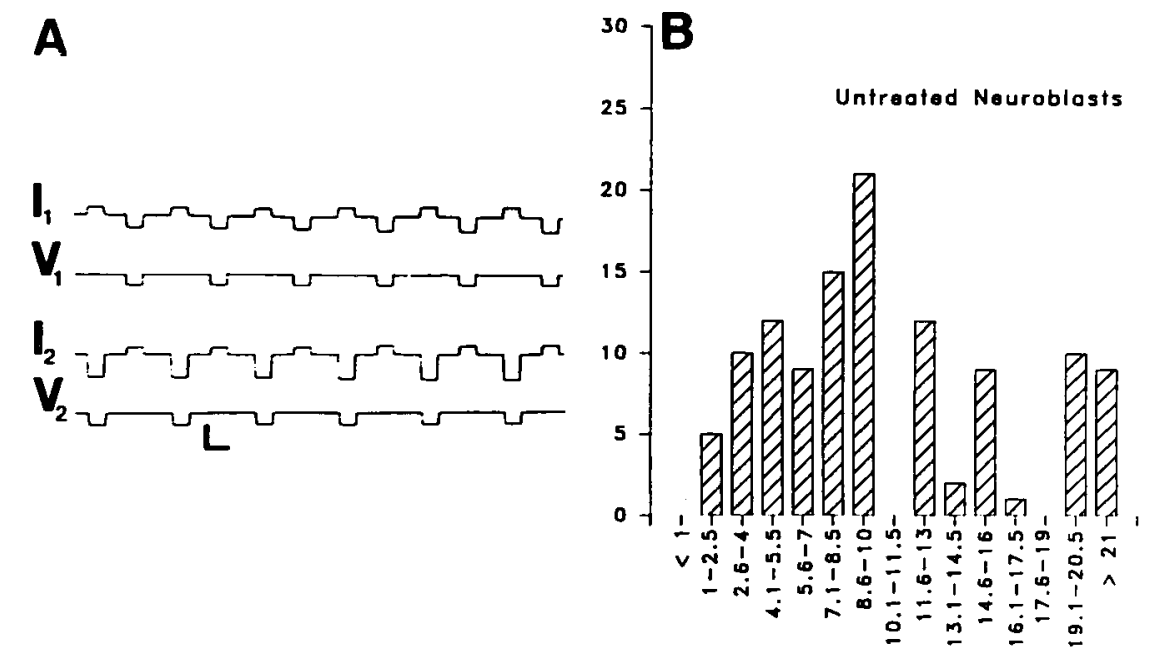

Figure 1. Junctional conductance measurements revealed that coupling strength is higher in the untreated neuroblasts than in cells that differentiated in response to either treatments. Untreated and cytokine-treated neuroblasts were cultured for the same length of time (1-7 DIV). $A$, Recording of macroscopic junctional conductance in a pair of untreated neuroblasts. Command voltage pulses were applied alternately to cells 1 and 2 . Currents recorded in the same cell in which the voltage step is applied represent the sum of conductances of junctional $\left(g_{\mathrm{j}}\right)$ and nonjunctional $\left(g_{\text {nj }}\right)$ membranes; junctional currents are recorded in the other cell. Calibration bars: horizontal, 1 sec; vertical, $10 \mathrm{mV}\left(V_{1}, V_{2}\right), 50 \mathrm{pA}\left(I_{1}, I_{2}\right) . B$, Histogram of junctional conductance $\left(g_{\mathrm{j}}\right)$ values obtained in 115 pairs of untreated neuroblasts. The mean value of $g_{\mathrm{j}}$ was $11.28 \pm 0.7 \mathrm{nS}$ (median, $10 \mathrm{nS}$ ). $C$, Histogram of $g_{\mathrm{j}}$ values obtained from neuroblasts treated with IL-7 alone $(n=60)$. Mean $g_{\mathrm{j}}$ was $6.51 \pm 0.77 \mathrm{nS}$ (median, $\left.5 \mathrm{nS}\right) . D$, Histogram of $g_{\mathrm{j}}$ obtained in 100 pairs of neuroblasts treated with bFGF(IL-7 and TGF $\alpha$ ). Mean $g_{\mathrm{j}}$ was $5.07 \pm 0.51 \mathrm{nS}$ (median, $\left.4 \mathrm{nS}\right)$.

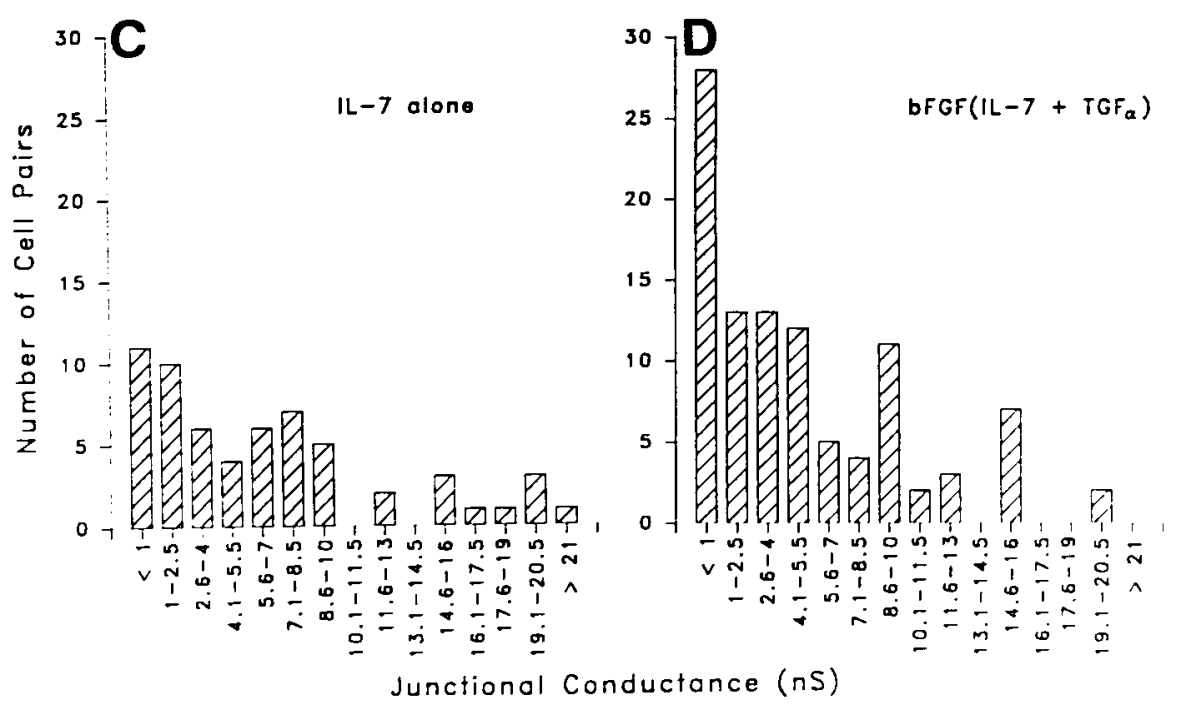

mental observations demonstrate a decline in $\mathrm{Cx} 43$ expression during differentiation, the appearance of $\mathrm{Cx} 40$ at an intermediate developmental stage, and the expression of $\mathrm{Cx} 33$ after treatment with neurogenic agents. Therefore, we speculate that the profile of expression of distinct connexin types during neuronal differentiation may play an instrumental role in this process, through the restriction and differential modulation of glial and neuronal signaling compartments.

\section{MATERIALS AND METHODS}

Cell culture. Immortalized hippocampal progenitor cells (MK31) were generated from embryonic day 17 mice as described previously, after transfection with a vector containing sequences encoding a temperaturesensitive allele of the SV40 large T antigen and a neomycin resistance gene (Mehler et al., 1993). In contrast to primary cultured neurons, this experimental system is genetically homogeneous, with an expandable developmental window and a self-renewing progenitor population that can be induced to undergo terminal differentiation (Mehler et al., 1993).

Neuroblasts were initially plated at $33^{\circ} \mathrm{C}$ at a density of $\sim 250,000$ cells $/ 35 \mathrm{~mm}$ Petri dish in DMEM serum-free medium containing $5 \mu \mathrm{g} / \mathrm{ml}$ insulin, $100 \mu \mathrm{g} / \mathrm{ml}$ transferrin, $20 \mathrm{~nm}$ progesterone, $100 \mu \mathrm{M}$ putrescine, 30 nM selenium, and $0.1 \%$ ovalbumin and were then switched to the temperature not permissive for $\mathrm{T}$ antigen expression $\left(39^{\circ} \mathrm{C}\right)$. Thereafter, the effects of two other treatment paradigms were studied (Mehler et al., 1993). In the first, IL-7 alone was added to the cultures. In the other, cells were pretreated with bFGF, and then TGF $\alpha$ and IL-7 were added in combination; this treatment paradigm is designated bFGF(IL-7 and
TGF $\alpha$ ) throughout the text. bFGF has mitogenic and trophic roles in the embryonic and postnatal development of the CNS; bFGF stimulates proliferation of neuronal precursor cells and glial cells and also supports the survival and differentiation of developing neuronal cells (Heuer et al., 1990; Walicke and Baird, 1991; Kinoshita et al., 1993). TGF $\alpha$ is known to guide cell growth and differentiation (Massague, 1990) and has been shown to stimulate the proliferation of striatal multipotent progenitor cells in vitro (Lazar and Blum, 1992). Growth factor concentrations were bFGF and TGF $\alpha, 5 \mathrm{ng} / \mathrm{ml}$; and IL-7, $10 \mathrm{U} / \mathrm{ml}$ (Mehler et al., 1993; Rozental et al., 1995). Control untreated neuroblasts and cytokinetreated neuroblasts were cultured for the same length of time and evaluated after 1-7 d in vitro (DIV) after treatment.

Electrophysiology. An inverted Nikon Diaphot TMF microscope was used to view cells continuously perfused with a solution containing (in $\mathrm{mM}$ ): $\mathrm{CsCl} 7, \mathrm{CaCl}_{2}$ 0.1, $\mathrm{NaCl} 160$, HEPES 10, and $\mathrm{MgSO}_{4}$ 0.6, $\mathrm{pH}$ 7.2. Junctional currents were evaluated using the dual whole-cell voltageclamp method (Neyton and Trautmann, 1985; White et al., 1985). Patchtype electrodes (resistance, 5-7 M $\Omega$ ) were filled with a solution containing (in mM): $\mathrm{CsCl} 135, \mathrm{CaCl} 0.5, \mathrm{Na}_{2} \mathrm{ATP} 2, \mathrm{MgATP} 3, \mathrm{HEPES} 10$, and EGTA 10, pH 7.2.

To measure macroscopic junctional conductance, each cell of a pair was clamped to a holding potential of $0 \mathrm{mV}$. Then, voltage commands of either polarity were applied alternately to each of the cells to generate a transjunctional driving force $\left(V_{\mathrm{j}}\right)$. Junctional conductance $\left(g_{\mathrm{j}}\right)$ was calculated by dividing junctional current recorded in the nonpulsed cell by the amplitude of the $V_{\mathrm{j}}$ pulse.

To reduce $g_{\mathrm{j}}$ to low levels, enabling recordings of single-channel currents, halothane ( $2 \mathrm{~mm}$ ) was added to the perfusate. Halothane has been shown to uncouple cells without changing unitary conductance 


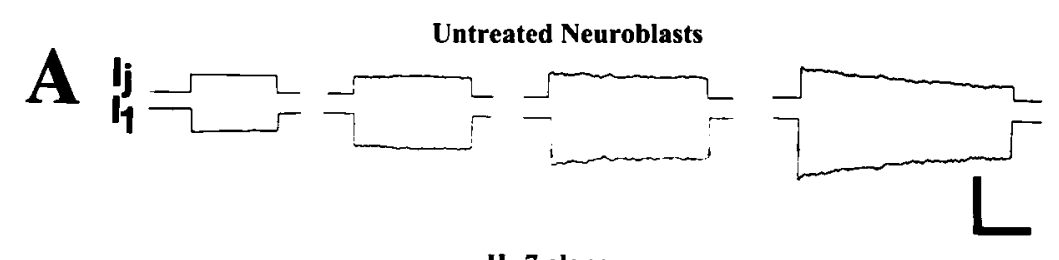

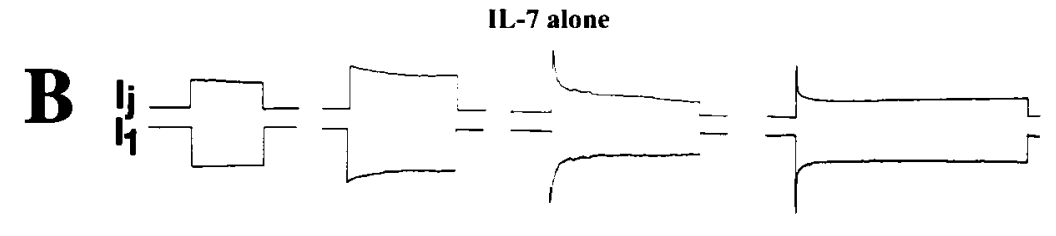

bFGF(IL-7 + TGF $\alpha)$
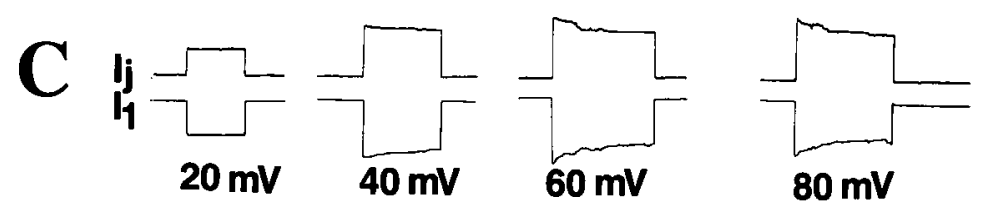

Figure 2. Voltage sensitivity of macroscopic $g_{\mathrm{j}}$ in untreated and treated neuroblasts by 2 DIV. Illustrated are typical current traces of recordings from representative cell pairs in which command pulses of $-20,-40,-60$, and $-80 \mathrm{mV}$ were applied to cell 1 , and junctional conductance was calculated from the junctional current $I_{\mathrm{j}}$ measured in the other cell. For all cell pairs, $I_{\mathrm{j}}$ was largest at the beginning of the voltage step and at higher voltages declined more rapidly during the command pulse to reach steady-state values of $g_{\mathrm{j}}$. $A, \mathrm{Re}$ sponses of untreated neuroblasts. $B$, Responses of neuroblasts treated with IL-7 alone. $C$, Responses of neuroblasts treated with bFGF(IL-7 and TGF $\alpha$ ). Difference in voltage sensitivity is most prominent when comparing responses at $60 \mathrm{mV}$. Calibration bars: vertical, $0.3,0.75$, and $0.15 \mathrm{nA}$ in $A, B$, and $C$, respectively; horizontal, $3 \mathrm{sec}$.
(Burt and Spray, 1989). Single-channel currents were identified as equalsized events of opposite polarity recorded simultaneously in the current trace of each cell. Recordings were made using Axopatch 1-C patchclamp amplifiers (Axon Instruments, Burlingame, CA), and hard copies of currents were obtained on a Gould chart recorder. The current amplitudes were then measured using a SummaSketch III digitizing tablet (Summagraphics Co., Seymour, CT) and computed using Sigma Scan software (Jandel Scientific, San Rafael, CA). Single-channel conductances $\left(\gamma_{\mathrm{j}}\right)$ were calculated by dividing unitary junctional currents $\left(i_{\mathrm{j}}\right)$ by driving force $\left(V_{\mathrm{j}}\right)$ and displayed as event histograms, normalized among different experiments. Mean values and their variances were calculated from Gaussian best fits to these histograms (Sigmaplot, Jandel Scientific).

To measure voltage sensitivity of macroscopic junctional conductance, long ( $\leq 1 \mathrm{~min}$ ) voltage pulses of up to $\pm 100 \mathrm{mV}$ were applied to one cell of a pair. Normalized steady-state junctional conductance $\left(G_{\mathrm{j}}\right)$ was calculated by normalizing the steady-state junctional conductance $\left(g_{\mathrm{ss}}\right)$ to the maximal junctional conductance $\left(g_{\max }\right)$ for each experiment; $G_{\mathrm{j}}$ values were plotted at each voltage $\pm \mathrm{SEM}$. The $G_{\mathrm{j}}$ versus $V_{\mathrm{j}}$ relation for each polarity of voltage was fitted assuming a two-state Boltzmann distribution of the form:

$$
G_{\mathrm{j}}=\left(G_{\mathrm{ss}}-G_{\min }\right) /\left(G_{\max }-G_{\mathrm{ss}}\right)=\exp \left\{-A\left(V_{\mathrm{j}}-V_{\mathrm{o}}\right)\right\},
$$

where $V_{0}$ is the transjunctional voltage at which the voltage-sensitive conductance is half-maximal, and $A$ is a parameter reflecting voltage sensitivity (from which equivalent gating charge, $n$, is calculated). $G_{\max }$, $G_{\min }$, and $G_{\mathrm{ss}}$ are normalized maximal conductance, minimal conductance approached at large $V_{\mathrm{j}}$, and experimentally derived steady-state junctional conductance, respectively.

To clarify the constituents of the population of junctional channels that were present in each treatment group, normalized event histograms were plotted for elemental junctional conductances. The frequencies of the $\gamma_{j}$ values were normalized by dividing the number of events of each conductance range (5 or $10 \mathrm{pS}$ bins) by the total number of events recorded for each cell pair. $\gamma_{j}$ values for all cell pairs were averaged for each treatment group, and means and SEs were calculated for conductances corresponding to each bin.

Northern blot and RT-PCR analyses. RNA was isolated from cultured cells using the Tri Reagent method (Molecular Research Center, Inc., Cincinnati, $\mathrm{OH}$ ), which includes phenol and guanidine thiocyanate in a monophase solution. The protocol includes the following five steps: homogenization, phase separation, RNA precipitation, RNA wash, and RNA solubilization. The cells were homogenized or lysed in Tri Reagent. After the addition of chloroform and centrifugation, RNA was precipitated from the aqueous phase by the addition of isopropanol, washed with ethanol, and solubilized. RNA was quantitated by absorbance measurements at 260 and $280 \mathrm{~nm}$ (Hitachi U-1100) with 1 OD unit considered equal to $40 \mu \mathrm{g} / \mathrm{ml}$. Integrity of RNA was analyzed by ethidium bromide staining followed by electrophoresis on a $1.2 \%$ formaldehyde-agarose gel. Cell RNA samples were treated with DNase I
(Boehringer Mannheim, Indianapolis, IN) to eliminate contamination with residual genomic DNA.

For Northern blot assays, total RNA was isolated from cells treated under different conditions; rat heart total RNA was used as a positive control for Cx43 (10 $\mu \mathrm{g}$ of total RNA/lane). The levels of loading of the RNAs were analyzed by ethidium bromide staining. Gels were capillaryblotted in $20 \times \mathrm{SSC}(3 \mathrm{M} \mathrm{NaCl}$ and $0.3 \mathrm{M}$ sodium citrate) onto GeneScreen membranes (DuPont, Wilmington, DE). RNA was UV-linked to the membrane by exposure to light at $254 \mathrm{~nm}$ (UV Stratalinker 2400; Stratagene, La Jolla, CA). The RNA blot was prehybridized in rapid hybridization buffer (Amersham, Arlington Heights, IL) for $1 \mathrm{hr}$ at $65^{\circ} \mathrm{C}$ and then hybridized in the same buffer for $2.5 \mathrm{hr}$ at $65^{\circ} \mathrm{C}$ after the addition of the denatured, random-primed probe. The rat cDNA probe used was full-length (1.3 kb) Cx43 (generously supplied by Dr. D. Paul, Harvard University Medical Center, Boston, MA). After hybridization, washes were performed once for $20 \mathrm{~min}$ at room temperature with $2 \times$ SSC and $0.1 \%$ SDS and twice for $15 \mathrm{~min}$ at $65^{\circ} \mathrm{C}$ with $0.1 \times \mathrm{SSC}$ and $0.1 \%$ SDS. The membranes were then exposed to RX film (Fuji Photo Film Co., Ltd.) at $-80^{\circ} \mathrm{C}$ for various periods.

For RT-PCR assays, first-strand cDNA synthesis was performed using the Superscript preamplification system (Life Technologies, Grand Island, NY). One to $2 \mu \mathrm{g}$ of total RNA was added to a final volume of 13 $\mu \mathrm{l}$ of DEPC-treated water and combined with $1 \mu \mathrm{l}$ of random hexamers $(50 \mathrm{ng} / \mu \mathrm{l})$. The mixture was heated at $70^{\circ} \mathrm{C}$ for $10 \mathrm{~min}$ and then incubated on ice. The remaining ingredients for reverse transcription were then added as follows: $2 \mu \mathrm{l}$ of $10 \times$ synthesis buffer $(200 \mathrm{~mm}$ Tris-HCl, pH 8.4), $0.5 \mathrm{M} \mathrm{KCl}, 25 \mathrm{~mm} \mathrm{MgCl}_{2}, 1 \mu \mathrm{g} / \mu \mathrm{l} \mathrm{BSA}, 2 \mu 10.1 \mathrm{M}$ DTT, $1 \mu \mathrm{l} 10 \mathrm{~mm}$ dNTP mix (10 mM each), and $1 \mu \mathrm{l}$ Superscript reverse transcriptase $(200 \mathrm{U} / \mu \mathrm{l})$. The reaction mix was left at room temperature for $10 \mathrm{~min}$ and incubated at $42^{\circ} \mathrm{C}$ for $50 \mathrm{~min}$, and the reaction was terminated by incubating at $70^{\circ} \mathrm{C}$ for $15 \mathrm{~min}$.

An oligonucleotide corresponding to a region of the first extracellular domain that is homologous among connexin sequences and a degenerate oligonucleotide complementary to the second extracellular domain (Haefliger et al., 1992) were synthesized on an Applied Biosystems (Foster City, CA) model 391 sequencer. Routinely, 24 bp sense and antisense "universal primers" were used: 5'-GGC TGT AAA AAT GTC TGC TAT GAC-3' and 5'-TGG GAC TGG AAA TGA AGC AGT-3'; these universal primers were designed to amplify the cytoplasmic loop regions of connexins (Haefliger et al., 1992), yielding amplicons of distinct sizes from group I or $\beta(350-390 \mathrm{bp})$ and group II or $\alpha(420-520$ bp) connexins (Bennett et al., 1991; Kumar and Gilula, 1996). PCR reactions contained 1-2 $\mu \mathrm{g}$ of first-strand cDNA, $50 \mu \mathrm{M}$ sense and antisense primers, $8 \mu \mathrm{l}$ of $10 \times$ PCR buffer (in mM: 100 Tris- $\mathrm{HCl}, 15$ $\mathrm{MgCl}_{2}$, and $500 \mathrm{KCl}, \mathrm{pH} \mathrm{8.3)}$ and $2.5 \mathrm{U}$ of Taq polymerase (Boehringer Mannheim) in a final volume of $100 \mu$ l. The samples underwent 30 cycles of PCR with a PTC-100 thermocycler (M. J. Research Inc., Watertown, MA) using the following parameters: (1) denaturation at $94^{\circ} \mathrm{C}$ for $30 \mathrm{sec}$, (2) annealing at $55^{\circ} \mathrm{C}$ for $30 \mathrm{sec}$, and (3) extension at $72^{\circ} \mathrm{C}$ for $30 \mathrm{sec}$. This was followed by a final extension cycle at $72^{\circ} \mathrm{C}$ for $10 \mathrm{~min}$ and a soak cycle 

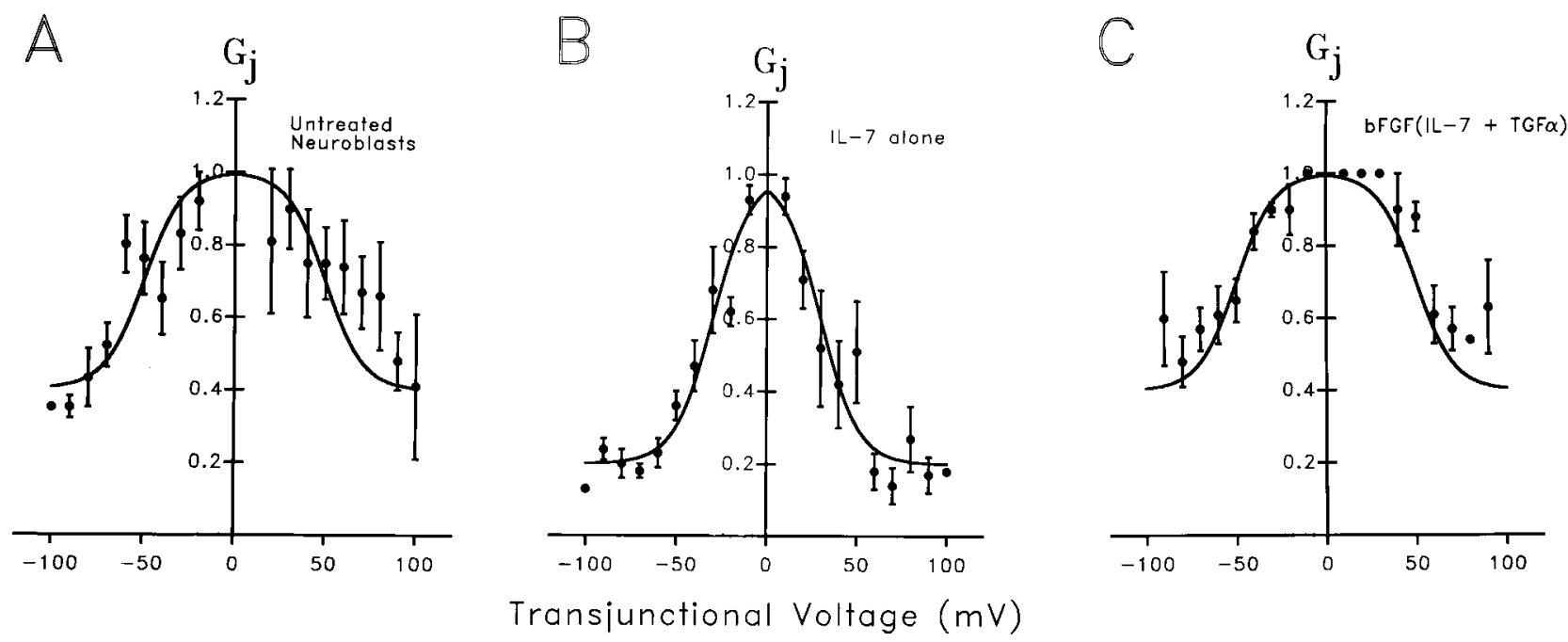

Figure 3. Boltzmann relations quantify the different sensitivities of junctional conductance to transjunctional voltage in untreated and cytokine-treated neuroblasts. Data obtained from the number of experiments indicated below are plotted as the steady-state $G_{\mathrm{j}}$ (value of $g_{\mathrm{j}}$ obtained at the end of the command pulse divided by initial conductance obtained at the beginning of the pulse). Mean $G_{\mathrm{j}}$ values at each transjunctional voltage ( $\left.V_{\mathrm{j}}\right)$ were fit by a form of the Boltzmann equation (see Materials and Methods) after subtraction of the minimal $G_{\mathrm{j}}\left(G_{\min }\right)$ value obtained at highest $V_{\mathrm{j}}$. $A$, Voltage dependence of $G_{\mathrm{j}}$ in 13 pairs of untreated neuroblasts. The best fit to the Boltzmann equation (solid line) was obtained with $G_{\min }=0.4 G_{\max }$; $V_{0}$ (the $V_{\mathrm{j}}$ values at which the voltage-sensitive component of $G_{\mathrm{j}}$ was reduced by $\left.50 \%\right)=50 \mathrm{mV}$; and $n$ (the equivalent gating charge) $=1.28$. $B$, Voltage dependence of $G_{\mathrm{j}}$ in 13 pairs of IL-7-treated neuroblasts; best fit to Boltzmann equation was obtained with $G_{\min }=0.2 \mathrm{G}_{\max } ; V_{0}=30 \mathrm{mV} ;$ and $n=1.25$. $C$, Voltage dependence of $G_{\mathrm{j}}$ in 11 pairs of neuroblasts after treatment with bFGF(IL-7 and TGF $\alpha$ ); Boltzmann parameters are very similar to those in untreated neuroblasts (i.e., $G_{\min }=0.4 G_{\max }$, and $V_{0}=50 \mathrm{mV}$ ).

at $4^{\circ} \mathrm{C}$. Reaction products were analyzed by electrophoresis on $2 \%$ agarose gels. Bands were isolated from gels and purified (Qiagen, Chatsworth, CA). The DNA was reamplified, and restriction digestion analysis with specific endonucleases (New England Biolabs, Beverly, MA) was performed on PCR products to distinguish specific connexin expression; unique restriction sites were deduced from the computer program PCGene (IntelliGenetics, Campbell, CA). These restriction enzymes included HincII, which cuts Cx43 sequence into two bands of 185 and 255 bp, and MseI, which results in bands of 170 and 265 bp from Cx33.

In addition, $\mathrm{Cx} 37$ - and $\mathrm{Cx} 40$-specific primers were used to verify the expression of these specific connexins at intermediate stages of neuroblast differentiation, as was suggested by our functional assays. Both sense and antisense Cx37-specific primers (5'-GGC TGG ACC ATG GAG CCG GT-3' and 5'-TTT CGG CCA CCC TGG GGA GC-3', respectively), designed to amplify a sequence of $421 \mathrm{bp}$, and the $\mathrm{Cx} 40-$ specific primers (5'-TTT GGC AAG TCA CGG CAG GG-3' and 5'TTG TCA CTG TGG TAG CCC TGA GG-3', respectively), designed to amplify a sequence of $311 \mathrm{bp}$, were used in our molecular assays. Murine brain and heart tissues were used as positive controls for $\mathrm{Cx} 37$ and $\mathrm{Cx} 40$, respectively.

Immunocytochemistry. Cultures grown on $12 \mathrm{~mm}$ glass coverslips (Assistent 1001; Carolina Biological Co., Burlington, NC) were rinsed once with Dulbecco's PBS and then permeabilized with acetone at $-20^{\circ} \mathrm{C}$. After several washes with PBS, the cultures were blocked with $0.1 \%$ bovine serum albumin in PBS. The primary antibody, affinity-purified IgG anti-connexin 43 serum [prepared against residues 346-360 of rat connexin 43 (Yamamoto et al., 1993); generously provided by Dr. E. L. Hertzberg, Albert Einstein College of Medicine, Bronx, NY], was diluted 1:100 in PBS. Incubation with the primary antibody was performed overnight at $4{ }^{\circ} \mathrm{C}$. Preimmune rabbit serum or PBS alone was substituted for the primary antibody as controls. After five washes with PBS, the cultures were incubated with goat anti-rabbit IgG conjugated to fluorescein isothiocyanate (Sigma, St. Louis, MO) in the dark for $1.5 \mathrm{hr}$ at room temperature. The cultures were washed several times with PBS and then briefly with distilled water and mounted on slides with $0.1 \%$ paraphenylenediamine (to resist photobleaching) in a 10:1 mixture of $33 \%$ glycerol and PBS. Cryostat sections of rat aorta were used as positive controls. Cultures were examined with epifluorescence illumination (Nikon Labophot) and photographed with Kodak (Rochester, NY) TMAX film.

Statistical analysis. Fisher's exact test for unpaired values was used to evaluate the significance of the differences between groups. Data are expressed as mean $\pm \mathrm{SEM}$.

\section{RESULTS}

\section{Macroscopic junctional conductance}

Neuroblasts under all treatment conditions were found to be coupled using the dual voltage-clamp method (Fig. 1A). However, differences were apparent among the macroscopic junctional conductances $\left(g_{\mathrm{j}}\right)$ recorded between neuroblasts in the three groups (Fig. $1 B-D)$. For untreated neuroblasts, $g_{\mathrm{j}}$ values averaged $11.28 \pm 0.7 \mathrm{nS}(n=115)$, with a median value of $10 \mathrm{nS}$ (Fig. $1 B)$. Neuroblasts treated with IL-7 alone had a mean $g_{\mathrm{j}}$ of $6.51 \pm 0.77$ $\mathrm{nS}(n=60)$ and a median value of $5 \mathrm{nS}$ (Fig. 1C). Neuroblasts treated with bFGF and then IL-7 and TGF $\alpha$ had a mean $g_{\mathrm{j}}$ value of $5.07 \pm 0.51 \mathrm{nS}(n=100)$ and a median conductance value of $4 \mathrm{nS}$ (Fig. 1D). Untreated cells were therefore more strongly coupled than cells of either treatment group $(p<0.0001)$. Although strength of coupling was slightly higher in cells treated with IL-7 alone than with the combination of cytokines, this difference was not significant $(p=0.1)$. However, the incidence of totally uncoupled neuroblasts in groups treated with the combination of cytokines was higher than in neuroblasts treated with IL-7 alone (26 vs $18 \%$; Fig. $1 C, D$ ).

\section{Voltage sensitivity of macroscopic junctional conductance}

When long transjunctional voltage $\left(V_{\mathrm{j}}\right)$ command pulses were applied to cell pairs from each group of neuroblasts, junctional currents relaxed toward lower conductance values during the pulses (Fig. 2). Current decays at low driving forces were most conspicuous for cell pairs treated with IL-7 alone, for which $V_{\mathrm{j}}$ values as low as $\pm 20 \mathrm{mV}$ led to detectable conductance decreases (Fig. 2B). By contrast, junctional currents in untreated neuroblasts (Fig. $2 A$ ) and those treated with the cytokine combination 

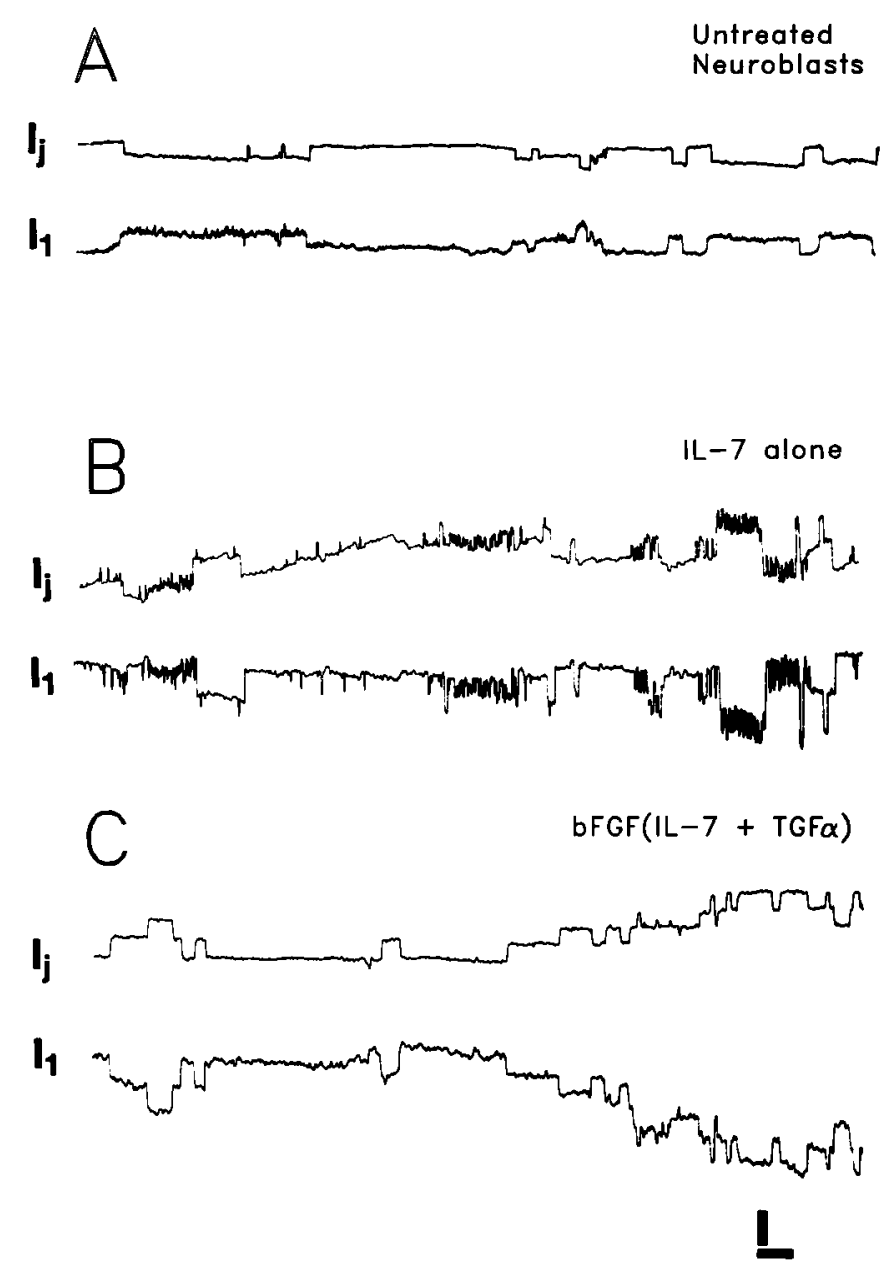

Figure 4. Single-channel recordings of junctional currents between pairs of untreated neuroblasts and neuroblasts treated with IL-7 and bFGF(IL-7 and TGF $\alpha$ ) by 2 DIV. Driving force $\left(V_{\mathrm{j}}\right)=30 \mathrm{mV}$. Untreated neuroblasts $(A)$ and those treated with the combined growth factors $(C)$ displayed unitary conductances in the range of 30-100 pS. Neuroblasts treated with IL-7 alone $(B)$ exhibited an additional population of unitary conductances in the range of 100-200 pS. Calibration bars: vertical, $5 \mathrm{pA}$ $(A, C), 10 \mathrm{pA}(B)$; horizontal, $2 \mathrm{sec}$.

were virtually insensitive to $V_{\mathrm{j}}$ pulses below $\pm 50 \mathrm{mV}$ (Fig. $2 C$ ). To quantify these differences, the ratio of steady-state conductance $\left(g_{\mathrm{ss}}\right)$ to initial conductance $\left(g_{0}\right)$ was plotted as a function of $V_{\mathrm{j}}$. For each treatment, these normalized $G_{\mathrm{j}} / V_{\mathrm{j}}$ plots were then fit by Boltzmann relations (Fig. 3). For both untreated neuroblasts (13 cell pairs) and cells treated with bFGF(IL-7 and TGF $\alpha$ ) (11 cell pairs) $G_{\min }$ (the minimal conductance at highest $\left.V_{\mathrm{j}}\right)=0.4, G_{\max }$ (the maximal conductance at low $V_{\mathrm{j}}$ ) $=1$, and $V_{0}=50 \mathrm{mV}$ (Fig. $3 A, C)$. For cells treated with IL-7 alone (13 cell pairs), $G_{\min }=$ $0.2, G_{\max }=1$, and $V_{0}=30 \mathrm{mV}$ (Fig. $3 B$ ).

\section{Properties of individual gap junction channels}

After treating cells with halothane to reduce $g_{\mathrm{j}}$ to low levels, single-channel currents could be visualized with driving forces as low as 20-30 mV (Fig. 4A-C). For each treatment group, $\gamma_{\mathrm{j}}$ values were of multiple sizes (Fig. $4 A-C$ ).

The normalized event histograms of unitary conductances were plotted in 10 or $5 \mathrm{pS}$ bins and fit with Gaussian distributions (see Materials and Methods). Distributions of events in the histograms with $10 \mathrm{pS}$ bins (Fig. $5 A-C$ ) revealed single-channel pop- ulations in both untreated and bFGF(IL-7 and TGF $\alpha$ )-treated cells (peaks at 55 and $64 \mathrm{pS}$, respectively), whereas the cells treated with IL-7 alone had two peaks, corresponding to 40 and $165 \mathrm{pS}$. Differences in the $\gamma_{\mathrm{j}}$ values between untreated and bFGF(IL-7 and TGF $\alpha$ )-treated cells and the lower peak in IL-7treated cells were not significant. Evaluating fits obtained to Gaussian distributions of data plotted in $5 \mathrm{pS}$ bins, we observed two peaks in single-channel measurements in untreated neuroblasts, corresponding to 43 and $64 \mathrm{pS}$. Analyzed in this way, neuroblasts treated with bFGF(IL-7 and TGF $\alpha$ ) showed two peaks of unitary conductance at 35 and $61 \mathrm{pS}$, similar to the control cells. By contrast, neuroblasts that were treated with IL-7 exhibited three peaks, at 35, 80, and $170 \mathrm{pS}$. Thus, channel populations in control and maximally differentiated neuroblasts were similar, whereas IL-7 treatment evoked functional expression of an additional population of large-conductance channels.

\section{Identities of connexins expressed in untreated and treated neuroblasts}

Neuroblasts were initially screened for expression of connexin mRNA by Northern blotting (Fig. 6). Cx43 mRNA was found to be highly expressed in untreated MK31 neuroblasts and was decreased during cellular differentiation in vitro. The level of Cx43 mRNA was evaluated both for short-term (1 d, 1 DIV; Fig. 6, top) and long-term (7 d, 7 DIV; Fig. 6, bottom) applications of cytokines. By $1 \mathrm{~d}$ after treatment (Fig. 6, top), changes in Cx43 RNA levels were not substantially different among untreated neuroblasts, neuroblasts treated with IL-7 alone, or those treated with bFGF(IL-7 + TGF $\alpha$ ). By contrast, after $7 \mathrm{~d}$ of cytokine treatment (Fig. 6, bottom), Cx43 mRNA could not be detected by Northern blot assays in either group of cytokine-treated MK31 cells; however, $\mathrm{Cx} 43$ mRNA in these preparations remained detectable using RT-PCR techniques (see below).

To evaluate the possible expression of other connexins in these cells after various cytokine treatments, we sought to optimize the conditions for detecting gap junctions by performing RT-PCR using universal primers that recognize all known connexins (Haefliger et al., 1992). In concert with the positive immunostaining obtained using $\mathrm{Cx} 43$ antibodies, a band corresponding to group II connexins was observed in both untreated and treated neuroblasts (Fig. 7A, lanes 1,3,5); RT-PCR products corresponding in size to group I connexins were not detected in any of these experimental groups. Restriction endonuclease digestion of the group II band from untreated cells using HincII resulted in the total conversion into 185 and 255 bp fragments, as expected for Cx43 sequence (Fig. 7B, lane 1). Sequence analysis of the undigested RT-PCR product revealed $99.1 \%$ identity with mouse Cx43 (PCGene; IntelliGenetics). By contrast, although treatment of group II bands from the IL-7 (Fig. 7B, lane 3) and bFGF(IL-7 and TGF $\alpha)($ Fig. 7B, lane 5) treatment groups with HincII also led to the predicted $\mathrm{Cx} 43$ digestion fragments, undigested RT-PCR product remained. The group II RT-PCR products were also exposed to the $\mathrm{Cx} 33$-specific restriction enzyme $\mathrm{Mse}$, resulting in fragments of the lengths expected for Cx33 (170 and $265 \mathrm{bp}$ ) in both treatment groups (Fig. $7 C$, lanes 3,5 ), but not in untreated cells (Fig. 7C, lane 1). Sequence analysis of this residual RT-PCR product revealed the presence of a product that was found to be 98.2\% identical to rat $\mathrm{Cx} 33$ (the sequence for murine $\mathrm{Cx} 33$ is not yet available).

Similar experiments using the restriction enzyme $B g l \mathrm{II}$, specific for mouse Cx37, and FspI, specific for mouse Cx40, revealed no detectable digestion fragments of the RT-PCR reaction product. 

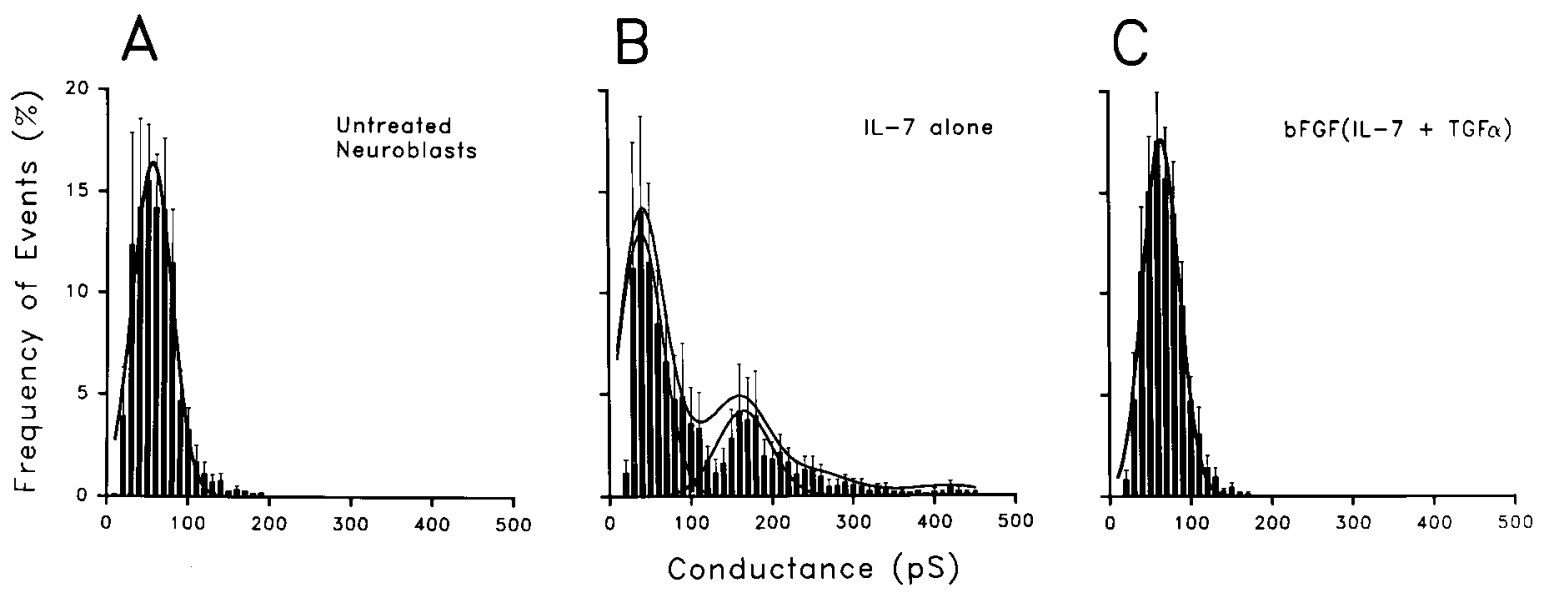

Figure 5. Normalized event histograms demonstrate the presence of a population of higher conductance channels in cell pairs treated with IL-7 alone than in untreated neuroblasts or after combined growth factor treatment. The frequency of conductance values obtained in each experiment was normalized by dividing the number of events of each conductance range ( 5 or $10 \mathrm{pS}$ bins) by the total number of events recorded for each cell pair. $A$, The normalized event histogram for untreated neuroblasts contains measurements of 1600 events obtained from 11 cell pairs. The Gaussian best fit to these data (solid curve) indicates a single event population with a peak at $55 \mathrm{pS}$. $B$, The normalized event histogram from neuroblasts treated with IL-7 contains 2052 event measurements obtained from nine cell pairs; two Gaussian curves are required to fit the data, with peaks at 40 and 165 pS. $C$, Normalized event histograms from neuroblasts treated with bFGF(IL-7 and TGF $\alpha$ ), consisting of 3300 events from 13 cell pairs; as in the untreated cells, a single Gaussian curve best describes the data with a peak at $64 \mathrm{pS}$.
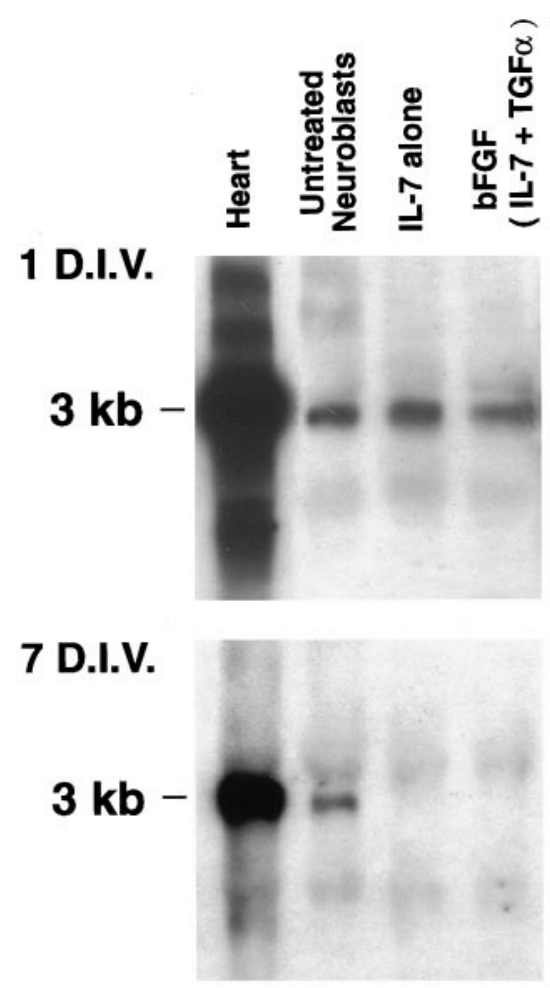

Figure 6. Levels of Cx43 mRNA decrease in treated neuroblasts. Northern blots of total RNA obtained from neuroblasts kept in culture for $1 \mathrm{~d}$ (1 DIV; exposure time, $2 \mathrm{~d}$; top) and $7 \mathrm{~d}$ (7 DIV; exposure time, overnight; bottom) at $39^{\circ} \mathrm{C}$. Under both conditions, all lanes were loaded with $10 \mu \mathrm{g}$ of total cellular RNA. Probes reacted with a single transcript at $3 \mathrm{~kb}$ for $\mathrm{Cx} 43$. Note the decrease in Cx43 RNA expression in cytokinetreated neuroblasts by 7 DIV. Heart, Mouse heart (control).

However, because we have observed that the use of universal primers to discriminate specifically between $\mathrm{Cx} 37$ or $\mathrm{Cx} 40$ is compromised when these connexins are co-expressed with $\mathrm{Cx} 43$ (Urban et al., 1996), we also used sequence specific-primers for these connexin types (Fig. $7 D, E)$. In cells at intermediate stages of neuronal differentiation (after IL-7 treatment), a product corresponding in size to $\mathrm{Cx} 40$ was detected using $\mathrm{Cx} 40$-specific RT-PCR primers (Fig. 7E, lane 2); these cells did not express products corresponding in size to $\mathrm{Cx} 37$ (Fig. 7D, lane 2). Positive controls for $\mathrm{Cx} 33$ (mouse testis; Fig. 7A,C, lane 7), $\mathrm{Cx} 43$ (rat heart; Fig. 7A,B, lane 9), $\mathrm{Cx} 37$ (rat brain; Fig. 7D, lane 1), and $\mathrm{Cx} 40$ (rat heart; Fig. $7 E$, lane 1) are illustrated. Untreated and treated neuroblasts ( 1 and 5 DIV) were immunostained with antibodies specific for $\mathrm{Cx} 43$ to reinforce our findings that $\mathrm{Cx} 43$ is one of the gap junction proteins expressed in these cells. Untreated cells showed high levels of $\mathrm{Cx} 43$ immunofluorescence, especially at sites of cellular membrane apposition (Fig. 8, $A, B, 1$ DIV, $G, H, 5$ DIV). Treated cells also displayed considerable Cx43 immunoreactivity by 1 DIV (Fig. $8 C, D$ ), although staining in the more differentiated cells was generally less intense than in phenotypically more immature cells nearby (Fig. $8 E, F$ ). In contrast, a pronounced reduction of $\mathrm{Cx} 43$ immunoreactivity levels in cytokine-treated neuroblasts occurred at 5 DIV (Fig. 8I-L). In contrast to $\mathrm{Cx} 43$ immunostaining, we have been unable to detect the expression of $\mathrm{Cx} 40$ or $\mathrm{Cx} 37$ unambiguously in cytokinetreated neuroblasts; antibodies specific for $\mathrm{Cx} 33$ are not yet available.

\section{DISCUSSION}

Previous studies have shown that electrotonic coupling among neurons decreases at early stages of nervous system development (Goodman and Spitzer, 1979; Connors et al., 1983; Walsh et al., 1989; Kandler and Katz, 1995), leading to the suggestion that there is a reciprocal relationship between strength of coupling via gap junctions and acquisition of the neuronal phenotype (Mehler et al., 1993; Mienville et al., 1994; Rozental et al., 1995; BaniYaghoub et al., 1997). Using a hippocampal progenitor cell line (MK31) and specific cytokine treatment regimens, we have shown previously that neuroblasts express gap junctions during early ontogeny, but that coupling strength decreases as neuroblasts progressively assumed the mature neuronal phenotype (Rozental et al., 1995). However, the connexin type(s) that are 
expressed in the neuroblasts, the possible changes that occur in connexin expression patterns during early development, and the functional implications of these changes for progressive stages of cellular differentiation remained to be determined.

The use of cell lines as research tools is well established. However, the concern always remains that responses of immortalized cells may diverge from their in vivo counterparts. In the case of the present study, Cx43 expression in neurons has been detected in adult rat brains by in situ hybridization methods and was found to occur in various neuronal populations, including Purkinje cells on the cerebellum, pyramidal cells on the neocortex, and the hippocampal formation, as well as granule cells on the dentate gyrus and neurons of diverse hindbrain nuclei (Simburger et al., 1997).

Junctional conductance between a pair of cells $\left(g_{\mathrm{j}}\right)$ is determined by the number of channels formed of each connexin type $\left(n_{1}, n_{2}, \ldots \mathrm{n}_{\mathrm{i}}\right)$ multiplied by the connexin-specific unitary conductances $\left(\gamma_{\mathrm{j}}\right)$ and their open probabilities $\left(g_{\mathrm{j}}=n_{1} P_{\mathrm{o} 1} \gamma_{\mathrm{j} 1}+\right.$ $\left.n_{2} P_{\mathrm{o} 2} \gamma_{\mathrm{j} 2}+\ldots n_{\mathrm{i}} P_{\mathrm{oi}} \gamma_{\mathrm{ji}}\right)$. Thus, the decline in coupling strength that has been observed to occur during neuronal ontogeny could result from: (1) downregulation of connexin gene expression (i.e., an overall decrease in $\left.\left[\left(n_{1}+n_{2}+\ldots n_{\mathrm{i}}\right)\right]\right),(2)$ changes in gating of the neuroblast junctional channels (i.e., changes in $P_{\mathrm{o}}$ or $\gamma_{\mathrm{j}}$ ), or (3) expression of different connexin subtypes (relative changes in $\left.n_{1}, n_{2}, \ldots n_{\mathrm{i}}\right)$. Each of these possibilities is considered below.

\section{Downregulation of connexin gene expression}

In contrast to detailed studies that have defined the connexin types present in glia (e.g., Dermietzel et al., 1989, 1991; Ransom and Kettenmann, 1990; Yamamoto et al., 1990; Giaume et al., 1991; Dermietzel and Spray, 1996), the connexins responsible for coupling in developing or adult neurons have not been reliably identified. However, there are indications that $\mathrm{Cx} 26, \mathrm{Cx} 32$, and Cx43 may be expressed in certain neuronal populations and under specific biological conditions (Dermietzel et al., 1989; Miragall et al., 1992; Bani-Yaghoub et al., 1997; Bruzzone and Ressot, 1997; Nadarajah et al., 1997; Simburger et al., 1997). It has been difficult to identify the specific connexin type(s) expressed in neurons during brain ontogeny, because coupling strength is lost as differentiation proceeds. In addition, the complex cytoarchitecture and diversity of cell types present within regions of the mammalian brain make it difficult to use traditional experimental techniques such as freeze fracture, thin-section electron microscopy, and immunological or molecular biological approaches to discriminate the "rare" neuronal gap junctions. Thus, the use of a conditionally immortalized hippocampal progenitor cell line that is readily amenable to pharmacological manipulation provides a well controlled, genetically homogeneous experimental model that can be used to address these questions.

In this study, we have used immunocytochemical and molecular biological methods to demonstrate that connexin 43 is highly expressed in early neuroblasts, in agreement with recent communications showing strong immunoreactivity to connexin 43 in rodent neurons during circuit formation (Nadarajah et al., 1997) and during neuronal differentiation of a human pluripotential teratocarcinoma cell line (Bani-Yaghoub et al., 1997). Furthermore, based on integrated RT-PCR analysis, Cx43 appears to be the only connexin expressed in early neuroblasts, consistent with our functional studies showing a uniform population of junctional channels with physiological characteristics typical of Cx43 (see below). Moreover, we have shown that $\mathrm{Cx} 43$ is downregulated during neuronal differentiation. However, even after cytokine applications that lead to maximal cellular differentiation, this connexin type remains. We therefore conclude that a decrease in the total number of junctional channels is one possible mechanism that may reduce junctional conductance during neuronal differentiation.

\section{Changes in gating of neuroblast junctional channels}

Each gap junction protein forms intercellular channels with distinct electrophysiological properties, including unitary conduc-

\section{Universal Primers}
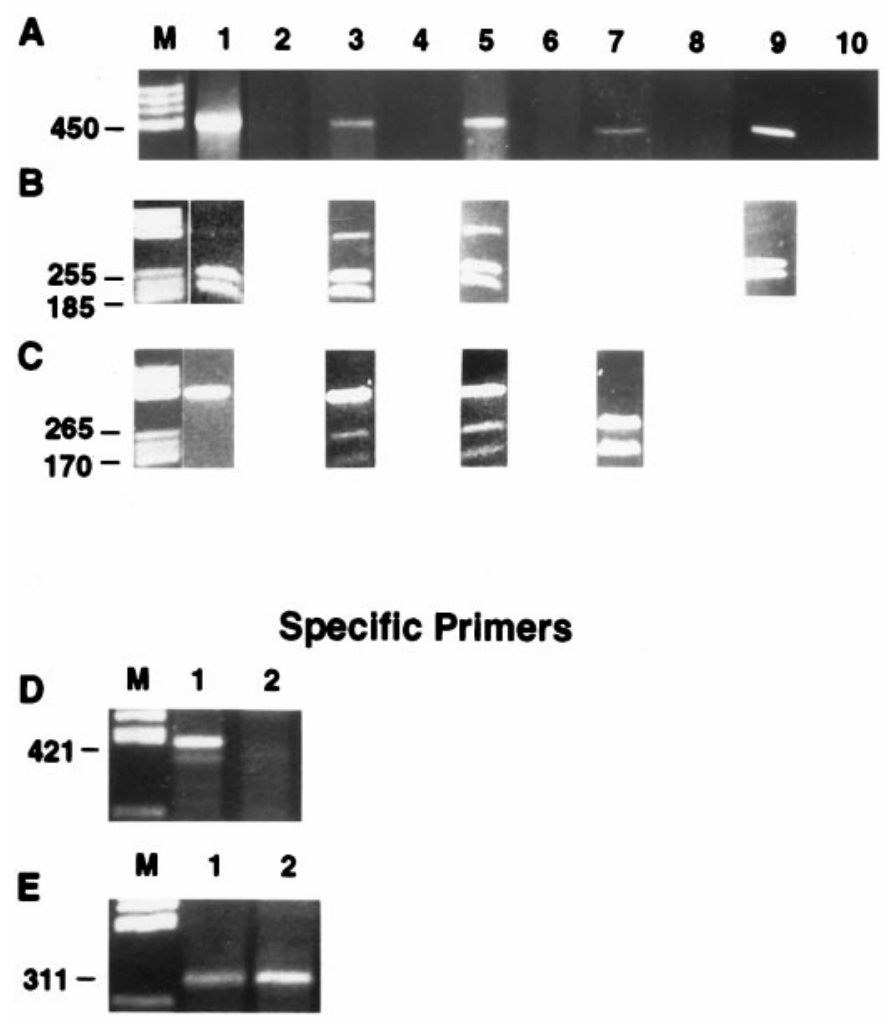

Figure 7. Determination of the connexin types expressed by differentiating neuroblasts by 7 DIV. $A$, Composite of gels from first-generation cDNA obtained by RT-PCR using universal primers, run on a $2 \%$ agarose gel, and visualized by ethidium bromide staining. Lanes 1, 3, and 5 show first-strand DNA from untreated cells, IL-7 alone, and IL-7 plus growth factors, respectively. Lanes 2 (untreated cells), 4 (IL-7), and 6 (IL-7 plus growth factors) are negative controls, run in PCR without reverse transcriptase to verify that genomic DNA was not present. Lane 7 is the PCR product of $\mathrm{Cx} 33$ from mouse testis, and lane 8 is its corresponding negative control. Lane 9 is the PCR product of $\mathrm{Cx} 43$ from rat heart, and lane 10 is its corresponding negative control. B. Presence of Cx33 and Cx43 confirmed by RT-PCR. Second-generation PCR product was obtained with universal primers. Lanes 1,3 , and 5 show the presence of restriction products of $\mathrm{Cx} 43$ after HincII was used. The product gave two bands for untreated, IL-7 alone, and IL-7 plus growth factors. Lane 9 is the HincII digest of the PCR product from the rat heart, which also gave the characteristic double band for Cx43. C, Lanes 1, 3, and 5 show the presence of the restriction product of Cx33 after MseI was used. This enzyme gave two bands for IL-7 alone and IL-7 plus growth factors. Lane 7 is the PCR product of the $\mathrm{Cx} 33$ from mouse testis that had been cut with MseI; two bands were formed. Sequencing the RT-PCR products revealed the presence of mouse Cx43 (99.1\% identical) and Cx33 (98.2\% identity with rat $\mathrm{Cx} 33$ sequence). Similar procedures applied with specific primers for $\mathrm{Cx} 37(D$, lanes 1,2$)$ and for $\mathrm{Cx} 40(E$, lanes 1,2$)$ in cells treated with IL-7 alone resulted in detection of a product of a $311 \mathrm{bp}$, consistent with the expression of $\mathrm{Cx} 40$. $M$, Molecular markers, PCR products of $\mathrm{Cx} 37$ (mouse brain; D, lane 1) and $\mathrm{Cx} 40$ (mouse heart; E, lane 1), respectively. 

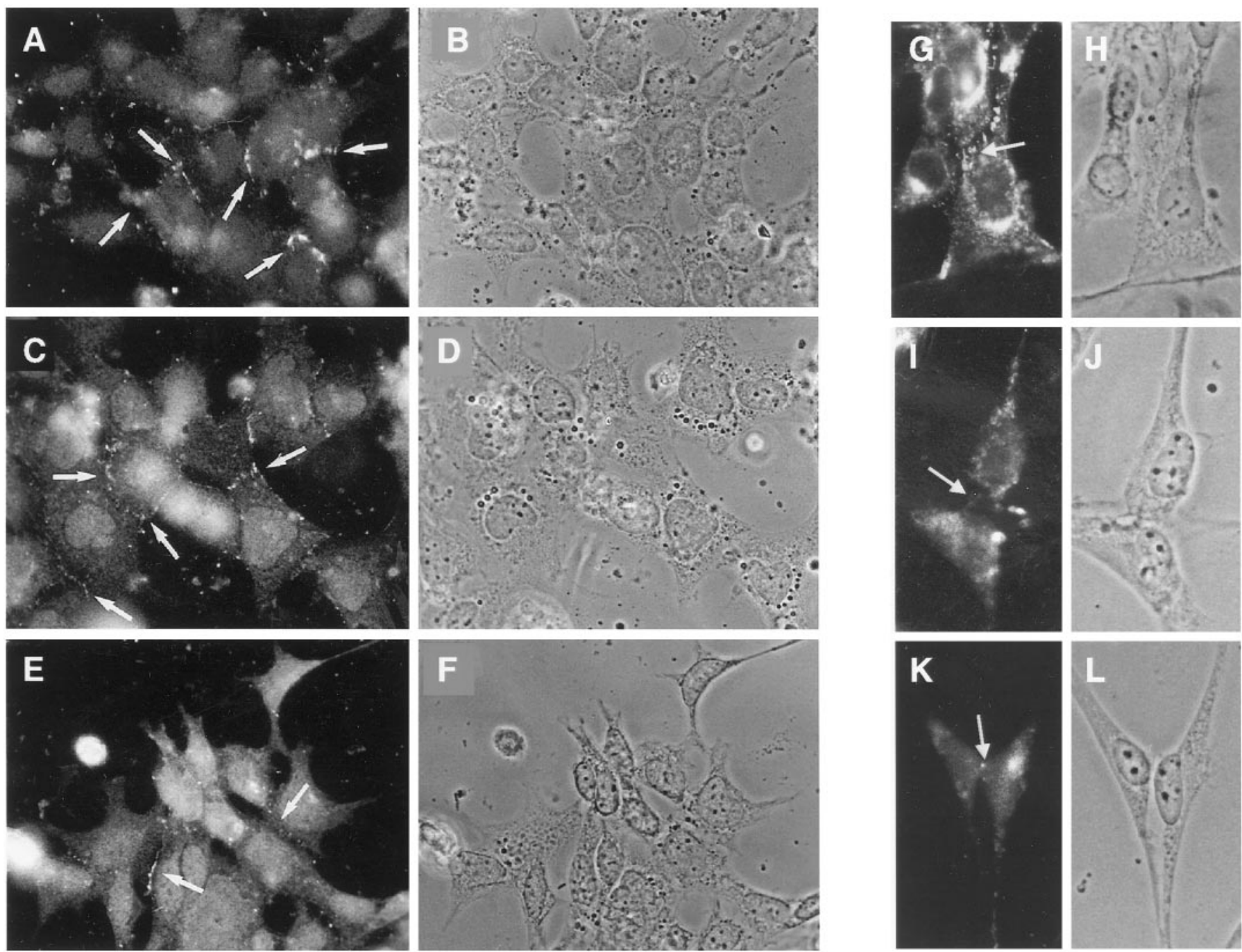

Figure 8. Immunofluorescent staining of $\mathrm{Cx} 43$ in MK31 neuroblasts by 1 DIV $(A-F)$ and at 5 DIV $(G-L)\left(39^{\circ} \mathrm{C}\right) . A, B, G, H$, Untreated cells. $C, D$, $I$, $J$, Cells treated with IL-7 alone. $E, F, K, L$, Cells pretreated with bFGF and then treated with IL-7 and TGF $\alpha . B, D$, and $F$ ( 1 DIV) and $H, J$, and $L$ (5 DIV) show the light microscopic photographs of the neuroblasts in different conditions. The white arrows $(A, C, E, G)$ indicate that most of the fluorescence is observed near the cell appositions. I, $K$, Presumptive immunofluorescence labeling for Cx43.

tances and sensitivities to various gating stimuli (Spray, 1996). For $\mathrm{Cx} 43$, the channels present in untreated neuroblasts, unitary conductance is dictated by the phosphorylation state of the channel protein and by transjunctional voltage (Moreno et al., 1994a,b). Moreover, channel open time is reduced by intracellular acidification and exposure to various amphophilic molecules (Spray, 1994), conditions that may occur as a consequence of ischemic insult. Nevertheless, changes in $\gamma_{\mathrm{j}}$ or voltage sensitivity were not detected in our electrophysiological experiments comparing junctional currents from immature neuroblasts to those of cells treated with the combination of growth factors. We thus conclude that such changes do not represent a major mechanism operating to decrease coupling strength in these cells during developmental transitions.

\section{Expression of different connexin subtypes during neuronal differentiation}

We have found that immortalized hippocampal neuroblasts express $\mathrm{Cx} 43$, that treatment with IL-7 alone leads to functional expression of $\mathrm{Cx} 40$, and that treatment with either IL-7 alone or in combination with bFGF and TGF $\alpha$ leads to co-expression of Cx33 by these progenitor species. The voltage sensitivity and unitary conductances of junctional channels recorded between cells treated with IL-7 alone resemble those recorded from channels formed by $\mathrm{Cx} 40$ expressed either endogenously or exogenously (Haefliger et al., 1992; Bruzzone et al., 1993; Hellmann et al., 1996) and in exogenously expressed channels in oocytes or N2A cells (Willecke et al., 1991; Reed et al., 1993). Interestingly, an additional complement of junctional channels corresponding to the expression profile of Cx33 was detected by RT-PCR but was not functionally detected after treatment with the combination of cytokines. These observations suggest that expression of Cx40 or another as yet unidentified connexin may be a transitory cellular event during neuronal differentiation, and that Cx33 may form nonfunctional channels, as suggested by exogenous expression studies in oocytes (Chang et al., 1996).

The expression of $\mathrm{Cx} 40$ and $\mathrm{Cx} 33$ by differentiating neuroblasts raises the intriguing possibility that the expression of specific connexin types may allow the segregation of coupled compart- 
ments, with compartmental boundaries defined by the specific type of connexin expressed. For example, functional channels are not formed by pairing Xenopus oocytes expressing Cx40 with those expressing Cx43 (Nicholson et al., 1993). Moreover, it has been suggested that $\mathrm{Cx} 33$ not only is nonfunctional in homotypic pairings but also may exert a dominant-negative effect, reducing coupling in cells in which it is co-expressed with other connexins (Chang et al., 1996).

The transient co-expression of $\mathrm{Cx} 43$ with $\mathrm{Cx} 40$ during the process of neuronal maturation has additional biological implications. Because mRNAs encoding $\mathrm{Cx} 43$ and $\mathrm{Cx} 40$ are also expressed in astrocytes (Dermietzel, 1996), homotypic channels of either connexin could mediate communication between neuronal precursor cells and astrocytes, providing a possible explanation for the observations that astrocytes may influence neuronal activity by direct signaling via gap junctions (Nedergaard, 1994). Such a cellular mechanism might underlie such diverse physiological and pathological processes as Leāo spreading depression (Leāo, 1947; Martins-Ferreira and Ribeiro, 1995; Nedergaard et al., 1995) or specific forms of epilepsy in which levels of $\mathrm{Cx} 43$ mRNA in the temporal cortex are increased (Naus et al., 1991).

In summary, our results show that hippocampal progenitor cells are highly coupled by gap junctions composed of connexin 43 during early ontogeny, before the functional expression of membrane electrical excitability and chemoresponsiveness to a variety of developmentally mediated neurotransmitters (Rozental et al., 1995). Because neuroblasts progressively differentiate, Cx43 expression decreases, and Cx33 is newly detected. In addition, $\mathrm{Cx} 40$ is also co-expressed at intermediate stages of neuroblast differentiation. Thus, although phenotypic changes that occur during neuronal differentiation parallel $\mathrm{Cx} 43$ downregulation, it remains to be determined whether there is a direct causal effect between downregulation of gap junction channels and neuronal differentiation.

\section{REFERENCES}

Araujo DM, Cotman CW (1993) Trophic effects of interleukin-4, -7, and -8 on hippocampal neuronal cultures: potential involvement of glialderived factors. Brain Res 600:49-55.

Bani-Yaghoub M, Bechberger JF, Naus CC (1997) Reduction of connexin43 expression and dye-coupling during neuronal differentiation of human Ntera2/clone D1 cells. J Neurosci Res 49:19-31.

Bennett MV, Barrio LC, Bargiello TA, Spray DC, Hertzberg E, Saez JC (1991) Gap junctions: new tools, new answers, new questions. Neuron 6:305-320.

Bruzzone R, Ressot C (1997) Connexins, gap junctions and cell-cell signaling in the nervous system. Eur J Neurosci 9:1-6.

Bruzzone R, Haefliger J-A, Gimlich RL, Paul DL (1993) Connexin 40, a component of gap junctions in vascular endothelium, is restricted in its ability to interact with other connexins. Mol Biol Cell 4:7-20.

Burt JM, Spray DC (1989) Volatile anesthetics block intercellular communication between neonatal rat myocardial cells. Circ Res 65:829-837.

Chang M, Werner R, Dahl G (1996) A role for an inhibitory connexin in testis? Dev Biol 5:50-56.

Connors BW, Benardo LS, Prince DA (1983) Coupling between neurons of the developing rat neocortex. J Neurosci 3:773-782.

Dermietzel R (1996) Molecular diversity of gap junction expression in brain tissues. In: Gap junctions in the nervous system (Spray DC, Dermietzel R, eds), pp 13-38. Austin, TX: Landes Bioscience.

Dermietzel R, Spray DC (1993) Gap junctions in the brain: where, what type, how many and why? Trends Neurosci 16:186-192.

Dermietzel R, Spray DC (1996) Gap junctions in the nervous system. In: Gap junctions in the nervous system (Spray DC, Dermietzel R, eds), pp 1-11. Austin, TX: Landes Bioscience.

Dermietzel R, Traub O, Hwang TK, Beyer K, Bennett MVL, Spray DC, Willecke K (1989) Differential expression of three gap junction pro- teins in developing and mature brain tissues. Proc Natl Acad Sci USA 86:10148-10152.

Dermietzel R, Hertzberg EL, Kessler JA, Spray DC (1991) Gap junctions between cultured astrocytes: immunocytochemical, molecular, and electrophysiological analysis. J Neurosci 11:1421-1432.

Furshpan EJ, Potter DD (1968) Low-resistance junctions between cells in embryos and tissue culture. In: Current topics in developmental biology, Vol 3 (Moscona A, Monroy A, eds), pp 95-127. New York: Academic.

Giaume C, Fromaget C, El Aoumari A, Cordier J, Glowinski J, Gros D (1991) Gap junctions in cultured astrocytes: single-channel currents and characterization of channel-forming protein. Neuron 6:133-143.

Goodman CS, Spitzer NC (1979) Embryonic development of identified neurons: differentiation from neuroblast to neuron. Nature 280:208-214.

Haefliger J-A, Bruzzone R, Jenkins N, Gilbert DJ, Copeland NG, Paul DL (1992) Four novel members of the connexin family of gap junction proteins. molecular cloning, expression and chromosome mapping. J Biol Chem 267:2057-2064.

Hellmann P, Winterhager E, Spray DC (1996) Properties of Cx40 gap junction channels endogenously expressed and exogenously overexpressed in human choriocarcinoma cell lines. Pflügers Arch 432:501-509.

Heuer JG, von Bartheld CS, Kinoshita Y, Evers PC, Bothwell M (1990) Alternating phases of FGF receptor and NGF receptor expression in the developing chicken nervous system. Neuron 5:283-296.

Kandler K, Katz LC (1995) Neuronal coupling and uncoupling in the developing nervous system. Curr Opin Neurobiol 5:98-105.

Kinoshita C, Heuer JG, Bothwell M (1993) Basic fibroblast growth factor promotes adhesive interactions of neuroepithelial cells from chick neural tube with extracellular matrix proteins in culture. Development 119:943-956.

Kumar NM, Gilula NB (1996) The gap junction communication channel. Cell 84:381-388.

Lazar LM, Blum MJ (1992) Regional distribution and developmental expression of epidermal growth factor and transforming growth factor- $\alpha$ mRNA in mouse brain by a quantitative nuclease protection assay. J Neurosci 12:1688-1697.

Leāo AAP (1947) Spreading depression of activity in the cerebral cortex. J Neurophysiol 7:359-390.

Lowenstein WR (1979) Junctional intercellular communication and the control of growth. Biochim Biophys Acta 560:1-65.

Martins-Ferreira H, Ribeiro LJC (1995) Biphasic effects of gap junctional uncoupling agents on the propagation of retinal spreading depression. Braz J Med Biol Res 28:991-994.

Massague J (1990) Transforming growth factor alpha. J Biol Chem 265:21393-21396.

Mehler MF, Rozental R, Dougherty M, Spray DC, Kessler JA (1993) Cytokine regulation of neuronal differentiation of hippocampal progenitor cells. Nature 362:62-65.

Mehler MF, Marmur R, Gross R, Mabie PC, Zang Z, Papavasiliou A, Kessler JA (1995) Cytokines regulate the cellular phenotype of developing neural lineage species. Int J Dev Neurosci 13:213-240.

Michaelson MD, Mehler MF, Xu H, Gross RE, Kessler JA (1996) Interleukin-7 is trophic for embryonic neurons and is expressed in developing brain. Dev Biol 179:251-263.

Mienville J-M, Lange GD, Barker JL (1994) Reciprocal expression of cell-cell coupling and voltage-dependent $\mathrm{Na}^{+}$current during embryogenesis of rat telencephalon. Dev Brain Res 77:89-95.

Miragall F, Hwang TK, Traub O, Hertzberg EL, Dermietzel R (1992) Expression of connexins in the developing olfactory system of the mouse. J Comp Neurol 325:359-378.

Moreno AP, Saez JC, Fishman GI, Spray DC (1994a) Human connexin43 gap junction channels-regulation of unitary conductances by phosphorylation. Circ Res 74:1050-1057.

Moreno AP, Rook MB, Fishman GI, Spray DC (1994b) Gap junction channels: distinct voltage-sensitive and -insensitive conductance states. Biophys J 67:113-119.

Nadarajah B, Jones AM, Evans WH, Parnavelas JG (1997) Differential expression of connexins during neocortical development and neuronal circuit formation. J Neurosci 17:3096-3111.

Naus CCG, Bechberger JF, Paul DL (1991) Gap junction gene expression in human seizure disorder. Exp Neurol 111:198-203.

Nedergaard M (1994) Direct signaling from astrocytes to neurons in cultures of mammalian brain cells. Science 263:1768-1771. 
Nedergaard M, Cooper AJL, Goldman SA (1995) Gap junctions are required for the propagation of spreading depression. J Neurobiol 28:433-444.

Neyton J, Trautmann A (1985) Single-channel currents of an intercellular junction. Nature 317:331-335.

Nicholson BJ, Suchyna T, Xu LX, Hammernick P, Cao FL, Fourtner C, Barrio L, Bennett MVL (1993) Divergent properties of different connexins expressed in Xenopus oocytes. In: Gap junctions (Hall JE, Zampighi GA, Davis RM, eds), pp 3-13. Amsterdam: Elsevier.

Ransom BR, Kettenmann H (1990) Electrical coupling, without dye coupling, between mammalian astrocytes and oligodendrocytes in cell culture. Glia 3:258-266.

Reed KE, Westphale EM, Larson DM, Wang HZ, Veenstra RD, Beyer EC (1993) Molecular cloning and junctional expression of human connexin37, an endothelial cell gap junction protein. J Clin Invest 91:997-1004.

Rozental R, Mehler MF, Morales M, Andrade-Rozental AF, Kessler JA, Spray DC (1995) Differentiation of hippocampal progenitor cells in vitro: temporal expression of intercellular coupling and voltage- and ligand-gated responses. Dev Biol 167:350-362.

Simburger E, Stang A, Kremer M, Dermietzel R (1997) Expression of Cx43 mRNA in adult rodent brain. Histochem Cell Biol 107:127-137.

Spray DC (1994) Physiological and pharmacological regulation of gap junction channels. In: Molecular mechanisms of epithelial cell junctions: from development to disease (Citi S, ed), pp 195-215. Austin, TX: Landes Bioscience.

Spray DC (1996) Physiological properties of gap junction channels in the nervous system. In: Gap junctions in the nervous system (Spray DC, Dermietzel R, eds), pp 39-59. Austin, TX: Landes Bioscience.
Urban M, Rozental R, Chiu FC, Kremer M, Dermietzel R, Spray DC (1996) Fast method for screening connexin-identity using RT-PCR assays. Soc Neurosci Abstr 22:582.

Walicke PA, Baird A (1991) Internalization and processing of basic fibroblast growth factor by neurons and astrocytes. J Neurosci 11:2249-2258.

Walsh JP, Cepeda C, Hull CD, Fisher RS, Levine MS, Buchwald NA (1989) Dye-coupling in the neostriatum of the rat: II. Decreased coupling between neurons during development. Synapse 4:238-247.

White RL, Spray DC, Campos de Carvalho AC, Wittenberg BA, Bennett MVL (1985) Some electrical and pharmacological properties of gap junctions between adult ventricular myocytes. Am J Physiol 249:447-455.

Willecke K, Heynkes R, Dahl E, Stutenkemper R, Hennemann H, Jungbluth S, Suchyna T, Nicholson BJ (1991) Mouse connexin37: cloning and functional expression of a gap junction gene highly expressed in lung. J Cell Biol 114:1049-1057.

Willecke K, Hennemann H, Dahl E, Jungbluth S (1993) The mouse connexin gene family. In: Progress in cell research, Vol 3 (Hall JE, Zampighi GA, Davis RM, eds), pp 33-37. Amsterdam: Elsevier.

Yamamoto T, Ochalski A, Hertzberg EL, Nagy JI (1990) On the organization of astrocytic gap junctions in rat brain as suggested by LM and EM immunohistochemistry of connexin43 expression. J Comp Neurol 302:853-883.

Yamamoto T, Hossain MZ, Hertzberg EL, Uemura H, Murphy LJ, Nagy JI (1993) Connexin43 in rat pituitary: localization at pituicyte and stellate cell gap junctions and within gonadotrophs. Histochemistry 100:53-64. 